\title{
A European Policy Agenda in and for the New Global Economy
}

\begin{abstract}
After almost thirty years of hyper-globalization, the global economic integration process has plateaued after the global financial crisis of 2008/09. However, this article argues that it is premature to announce globalization's death. Rather, it posits that globalization is changing its character. Key features of the "new global economy" explored are: digitalization, the rise of superstar firms, the rise of emerging economies, and the changing geography of global finance. At the same time, the distributional consequences of both hyper-globalization of the past and the key structures of the new global economy have the potential of undermining political support of globalization and have been linked to the rise in populism in advanced countries. Taking into account the political challenges emanating from globalization, the article finishes by discussing policy options for the European Union. It argues, that is not enough to address the economic and distributional issues efficiently, but that is also urgent to rebalance and democratize EU governance to give Europe the legitimization and, hence, the credibility to act globally in support of a just and stable global economy.
\end{abstract}

Keywords: Digitalization; Superstar Firms; Emerging Economies; Global Finance; Populism; European Governance.

\section{Introduction}

Globalization has been slowing down. At the same time, populism and old-style protectionism is on the rise. This article seeks to identify the major disruptions in and to global economic integration and its policy implications from a European perspective.

From the late 1980s onward, cross-border economic activities had been growing considerable faster than global production. However, after the global financial crisis (GFC) of 2008/09, this phase of about thirty years of "hyperglobalization" has given way to what some consider to be a "new normal": trade and foreign direct investment (FDI) are stalling relative to production, 
and a retrenchment of cross-border finance has been setting, especially in banking (see Figure 1). This article has two major objectives: First, it argues that it is premature to announce globalization's death. Rather, it will show that globalization is merely changing its character. Second, it will explore the implications of this "new global economy" from a European policy perspective.

Figure 1. Cross-Border Activities Relative to World GDP, 1980-2017 (1980=100)

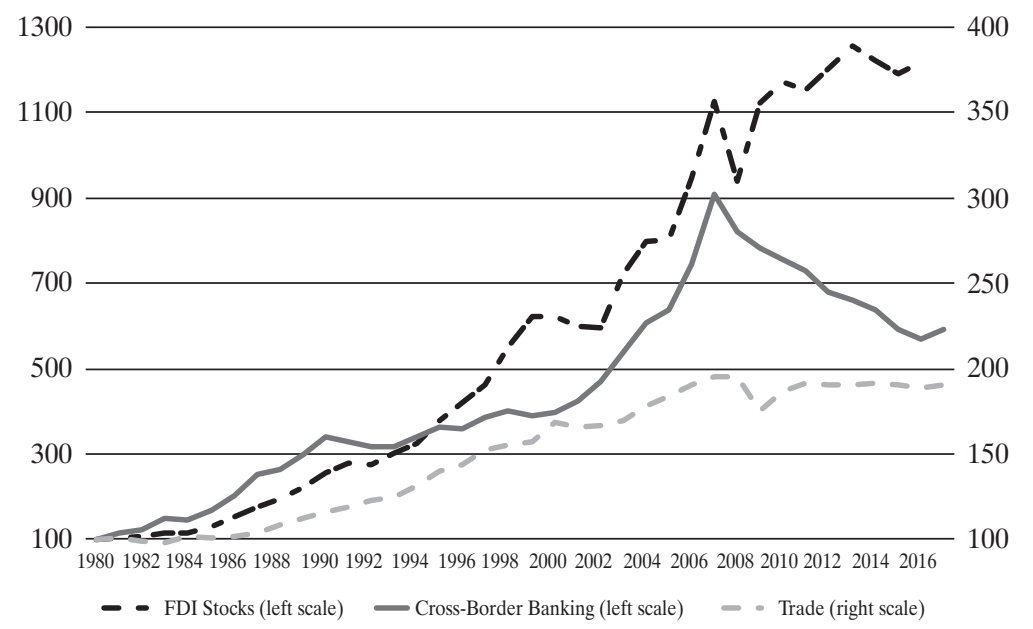

Source: Own calculation based on IMF World Economic Outlook Database (GDP, Trade), UNCTAD (FDI), and BIS Locational Banking Statistics (Cross-Border Banking). FDI stocks are measured as the average of inward and outwards stocks. Cross-border banking is measured as the average stocks of cross-border liabilities and claims.

Like in the past, the interaction of technological developments and policy will continue to determine the pace and character of global economic integration and, hence, its effects on people. On the technological side, especially digitalization and robotics will reshape the global economy as much as the steam engine has done it from 1870 to 1914, and information and communications technology (ITC) from the 1990s onward. On the political side, the opening-up euphoria of the $90 \mathrm{~s}$ and $00 \mathrm{~s}$, advocated as a panacea to many if not all economic woes by the so-called Washington Consensus (Williamson, 1990), has lost its appeal after the GFC has shown the vulnerability of financially closely interconnected economies. Additionally, as both technologies and globalization are threatening the standard of living not only of the low-skilled, but make deep inroads into the middle class, populist movements are increasingly pushing a political backlash against globalization in several advanced countries. Old-style protectionism with nationalistic undercurrents has become popular again and reminds observers of 
the sinister $20^{\text {th }}$ century interwar period that ultimately helped destroying the world economic order. Whether populism and nationalism will repeat its malign impact on the global economy will depend crucially on how policy makers will deal with the dual challenges emanating from technology and globalization.

In this article I will explore these issues from a European perspective. Section 2 seeks to identify the major drivers of current and future globalization in general, and their impact on Europe in particular. Based on this analysis, the link between globalization and the rise of populism especially in Europe is reviewed in section 3. European policy options and the quest for a reform of the European Union to deal with the emerging new global economy is discussed in section 4. Section 5 concludes.

\section{Towards a New Global Economy}

\subsection{The Rise of Global Value Chains}

From the mid-1980s onward, technology advancements in ICTs as well as a global political drive towards deregulation and opening-up economies, enabled corporations to globalize quickly. With the emergence of computer-aided design, computer-numerical controlled production and computer-aided manufacturing, value chains could suddenly be "sliced-up": the production of a product was "unbundled" in several tasks in a way that these tasks fit perfectly until final assembly takes place. Production of many goods no longer needed to take place in a single factory. These new possibilities for slicing-up the value chain are being used whenever it becomes profitable to do so. This can, of course, be done within a country or even within a narrowly defined region. In effect, domestic outsourcing is common, too. However, given the much bigger differences between production costs and the much greater variety of specialized skills on a global scale, the globalization of value chains can offer much more efficient opportunities than pure domestic ones. This also depends on one more thing: reasonable information and communication costs. This is exactly what happened from the 1990s onward: increasing possibilities for slicing-up the value chains coupled with drastically falling information and communication cost. As a consequence, value chains were sliced-up and offshored, thus giving rise to what has become known as global value chains (GVCs). A tremendous relocation of production tasks took place from the late 1980s onwards, largely driven by FDI. Emerging economies, especially in South-East Asia, that quickly understood that they 
could benefit from these investments tremendously, opened-up their economies to trade and FDI, deepened regional free trade agreements and countries like China were eager to join the World Trade Organization (WTO). Especially these countries were able to gain tremendously from this new type of "labor arbitrage" by participating in the global value chains of major industries, in particular in clothing and electronics. In Europe, the Central and Eastern European Countries (CEECs) became a significant part of the regional production networks of major West European industries, with an important role of the automobile industry. And in the Americas, the Mexican maquiladora industry involved itself deeply in the North American value chain.

It is noteworthy that global value chains are often regionally concentrated. ${ }^{1}$ For example, in the electronics industry suppliers of intermediate inputs are often also located in one region, in this case in East Asia. This creates a lot of intra-regional trade within relatively short distances, which make regional trade agreements an important policy instrument to promote the regional clusters. Only when the final product is delivered to the consumer market, trade becomes truly global. A similar pattern can be observed in the European car industry, where especially the German automobile industry has created regional production networks, in particular involving CEECs.

Since the global financial crisis, trade and foreign investment growth has slowed down. Why is globalization stalling, will it eventually revive and if yes, in what configuration? In other words, are we witnessing just a temporary halt or a structural shift? While this is partly the effect of the great recession that followed the GFC and - in Europe - especially the Euro crisis from 2010 onward, and hence eventually a temporary effect, it is also argued that GVCs have entered a stage of diminishing returns: everything that could be sliced-up has already been sliced-up. In fact, growth in GVCs has recently stagnated. While the share of foreign value added in trade has increased from $24 \%$ in 1990 to $31 \%$ in 2010 , it is now down to $30 \%$ in 2017 . But it is noteworthy that the share is with $38 \%$ still very high in Europe (UNCTAD, 2018).

However, there may be also other technological, economic and political factors behind the slow-down of trade, investment and GVC creation. To understand where the global economy eventually will go from here, I will review

1 This is also reflected by the so-called "distance puzzle" found in estimates of gravity models of trade. The gravity model postulates that trade between two countries is proportional to the product of the economic size of the countries and inversely related to the geographical distance that separates them. The distance puzzle relates to the finding of most gravity studies that sizeable distance effects not only still exist, but despite falling transportation and ITC costs have increased in recent times. Regional production networks go a long way explaining the distance puzzle. 
four major potential disruptors: digitalization through further advances in ICT, the rise of superstar firms, the (further) rise of new emerging market countries, and the emergence of new pattern of global finance after the GFC.

\subsection{Digitalization}

While ICT and digitalization has allowed the slicing-up of the value chain to an extreme amount, digitalization has more in store than just creating GVCs to change the intensity and character of globalization, namely robotization, machine learning, i.e. artificial intelligence (AI) and a potential of reducing face-to-face communication costs through virtual reality (VR) and augmented reality (AR) applications (see Baldwin, 2016).

To start with, robotization has in principle nothing to do with offshoring as a robotized production process can take place domestically or offshore. In the first case, a domestic job would be replaced by a robot, in the second case it would replace a foreign job. The matter of interest here is how robotization will impact the geography of global production. This depends on what it does to production costs: When the prices of machines (capital) fall relative to the cost of the labor that these robots would replace, a shift to machine production will take place. Here, two observations are important: First, the price of capital is indeed falling (see e.g. Nordhaus, 2015) and second, the cost of labor especially in fast growing emerging economies, like China and South-East Asia, are rising. Given that many tasks have been offshored to low-labor-cost locations, these effects can thus induce reshoring. Moreover, reshoring may be re-enforced by a market-size effect, which will shift production closer to consumers.

The important point is that intelligent robots may not simply overtake whole production process but just tasks, namely those that are most easily to robotize. In a recent paper, Acemoglu and Restrepo (2018, p. 48) model task-based automation. They argue that technologies most threatening to labor "are not those that are major breakthroughs increasing productivity greatly, but those that are "so-so"- good enough to be adopted but not so good that they increase productivity by much." As a consequence, reshoring of tasks is increasingly becoming a real phenomenon, not least in Europe. Marin et al. (2017) identify a changing pattern of offshoring, which indicates that the slowing-down of GVC trade is characterized by a new form of globalization with firms restructuring their value chains to become shorter and more local and regional. The authors also find sizeable relocation effects, not least driven by reshoring of Chinese companies. In Europe they find significantly less offshoring to southern European countries and instead a move towards China and the CEECs. 
AI is the second main potential technological disruptor. With machine learning developing fast, the regional concentration on the US on the one hand and China on the other hand is striking. In other words, Europe is largely absent in the development and in particular the exploitation of AI, which requires access to huge data to allow for machine learning. Two business models are thus dominating: the data-commercializing model of US data giants and the "state-collecting-data" model of China.

The third potential disruption may come via decreasing face-to-face communication costs as argued forcefully by Richard Baldwin (2016). Telepresence, tele-conferencing, tele-robotics, VR and AR may allow to reduce travel cost and might thus allow countries that previously were grossly unrepresented in the GVC-driven globalization of the last 30 years to develop new competitive advantages based on labor cost differentials, which finally have the potential to connect remote countries like Argentina as much as land-locked countries in Africa and Asia, which have not been part of the "great convergence" process in the global economy. These cross-border activities will take place in merchandise trade but in trade in (labor) services - another new form of globalization.

\subsection{The New Global Firms}

Rapidly growing global digital multinational enterprises (MNEs), trade in intangibles, and tax-optimizing FDI are gaining in relative importance in cross-border activities at the expense of trade in goods and FDI in manufacturing.

Figure 2. Global FDI Inward Stock by Sector, 2001, 2007, 2015 (Trillions of Dollars)

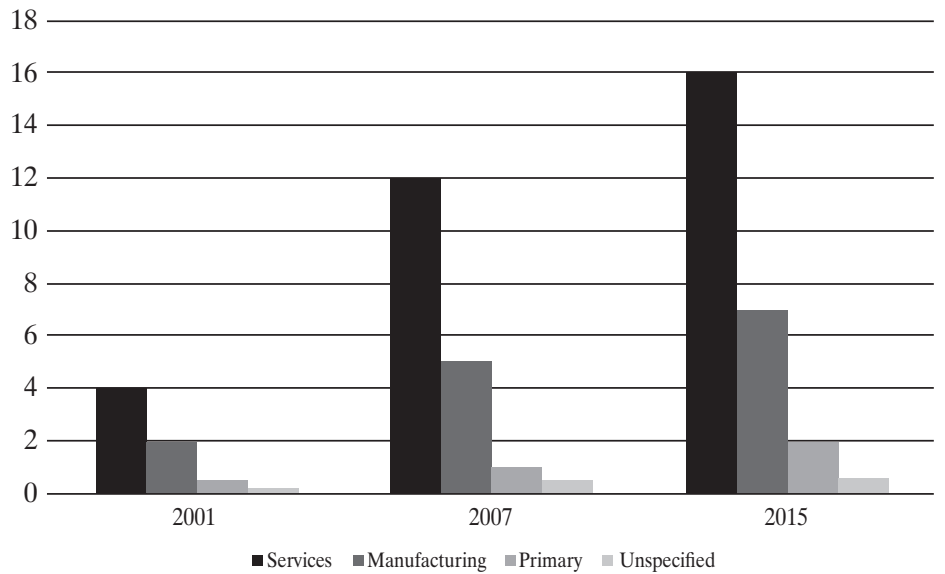

Source: UNCTAD, 2017, p. 21. 
Trade in intangibles comprise services and well as trade in knowledge. To start with the least spectacular observation, it is now well-documented that FDI in services is dominating overall with a share of above $60 \%$. Nevertheless, this number is by-and-large in line with the overall share of services in the global economy. ${ }^{2}$ However, the previous secular trend towards FDI in services has leveled-off after the financial crisis, suggesting that FDI services are often directly linked to activities in manufacturing or in the primary sector (see Figure 2). Nevertheless, as today more than half of all global FDI flows are going to developing countries and countries in transition, where the share of the service sector has been relatively low, this also signals a catching-up of the latter in services.

The structural changes are more drastic when it comes to the geography of and trade in know-how. While the global stock of knowledge and technology was in the past concentrated in advanced countries, knowledge is increasingly crossing borders and rapidly rising innovation activity in emerging economies, especially in Korea and China, as documented in a recent IMF study that uses patenting statistics (IMF, 2018). Knowledge typically travels with trade, FDI, migration and other cross-border activities. Hence, it has directly and indirectly been driven by the advancements in ICT. Participation in GVCs appears to play an important role for knowledge spillovers and patenting activity. The authors of the IMF study find that the "overall effect on patenting of the average firm is positive, with the observed 1 percent increase in GVC participation every five years explaining one-tenth of the increase in patenting in the average firm over the same period" (IMF, 2018, p. 15). Based on an additional analysis of crosspatent citations, the authors also document the rise in trade in know-how and increasing importance of south-north trade and south-south trade in knowledge.

From the perspective of the traditional innovating advanced countries, the transfer of knowledge is a two-sided sword. On the one hand, selling knowhow becomes increasingly a major source of income, hence generating direct benefits for the innovating companies. As more widely-spread knowledge can boost productivity and incomes in the receiving economy, it may also contribute indirectly to a higher demand for the innovating companies' products. The downside is, whether or not the proper price is paid for the know-how, thus compensating for eventually increasing competition.

2 It should be noted, though, that the data on the share of services is somewhat inflated. According to UNCTAD (2017: 21), a "large part of global FDI in services is in business activities, including functions carried out by holding companies and regional headquarters that are allocated to services by default, even though parent companies might operate in the primary or manufacturing sector." 
As such, the core of the issue lies in creating a fair and level playing field. The problem is twofold: First one has to strike a proper balance between innovators and imitators, and second, as it is well documented by now, trade in know-how is often used for tax-avoidance purposes via transfer pricing.

Finally, with respect to the new global digital superstar firms, especially the so-called "big five": Alphabet, Apple, Amazon, Facebook and Microsoft, five important observations need to be made.

First, superstar firms in the digital business are typically "winner-takes-all/ most" firms. The digital markets are characterized by strong network externalities and, hence, a lack of effective competition, thus generating extremely high supernormal profits.

Second, superstar firm are a strong driver behind the secular fall in labor shares. Van Reenen (2018, p. 21) notes that "large 'superstar' firms will tend to have higher profit margins and lower labor shares of value added". This, however, is not true for the typical US firm, as documented by Autor et al. (2018). Hence, Van Reenen continues to explain that "[W]hat explains the fall in the aggregate labor share and rise in the markup is a reallocation towards the larger and more productive firms". In other word, a rising share of superstar firms in the national value-added reshuffles income shares from labor to capital.

Table 1. International Footprint of Top 100 Multinational Enterprises (MNEs), 2015

\begin{tabular}{|c|c|c|c|c|}
\hline & Tech MNEs & Telecom MNEs & \multicolumn{2}{|c|}{ Other MNEs } \\
\hline Share of Foreign Assets & $41 \%$ & $66 \%$ & & $65 \%$ \\
\hline Share of Foreign Sales & $73 \%$ & $57 \%$ & & $64 \%$ \\
\hline $\begin{array}{l}\text { Ratio Share of Foreign } \\
\text { Sales to Foreign Assets }\end{array}$ & 1.8 & 0.9 & \multicolumn{2}{|r|}{1.0} \\
\hline & of which: & & \multicolumn{2}{|l|}{ of which: } \\
\hline & Internet Platforms & 2.6 & $\begin{array}{l}\text { Automotive } \\
\text { and Aircraft }\end{array}$ & 1.3 \\
\hline & $\begin{array}{l}\text { Digital Payments } \\
\text { and other digital } \\
\text { Solutions }\end{array}$ & & & \\
\hline & IT & & & \\
\hline & E-Commerce & & & \\
\hline & Digital Content & & & \\
\hline
\end{tabular}

Source: Based on UNCTAD, 2017, p. 170 and 171.

Third, the international footprint of digital MNEs is profoundly different from that of other MNE, as documented by UNCTAD (2017). Table 1 shows that 
they require only a share of about $40 \%$ of total assets to locate abroad to reach foreign markets and to generate $70 \%$ of their sales abroad. Hence, the relation of foreign sales to foreign assets is 1.8 as opposed to a one-to-one relationship for other MNEs. The relation is especially high for MNEs providing internet platforms, digital solutions as well as for IT firms (software and services, devices and components). As a consequence, these firms generate less investment and employment in the countries they serve with their products than non-digital MNEs.

Fourth, digital MNEs are more closely linked to their home countries than other MNEs. Moreover, they are headquartered in only a few countries, with an obvious concentration in the United States.

Fifth, the high share of foreign earnings in total earnings is often neither remitted to the home country nor used to finance foreign productive capacity, in a way comparable to non-tech MNEs (see Table 2). UNCTAD (2017, p. 174) therefore conjectures from an analysis of US MNE behavior: "The main objective is rather to minimize the tax burden by (indefinitely) deferring the payment of the tax adjustment upon repatriation of foreign earnings to the United States. Accordingly, tech MNEs incurred an average effective tax rate of 19 per cent in 2015 - significantly lower than the tax rate paid by other United States MNEs. These patterns are likely to apply to digital MNEs as well, given the common characteristics they share with tech MNEs". ${ }^{3}$

Table 2. Foreign Earnings, and Effective Tax Rate of United States MNEs in UNCTAD's Top100 MNEs, 2015

\begin{tabular}{|l|c|c|c|}
\hline & $\begin{array}{c}\text { Share } \\
\text { of Total Foreign Earnings }\end{array}$ & $\begin{array}{c}\text { Ratio of unremitted foreign } \\
\text { earnings to tangible assets }\end{array}$ & Effective tax rate \\
\hline Tech MNEs & $62 \%$ & 6 & $19 \%$ \\
\hline Other MNEs & $23 \%$ & 1 & $27 \%$ \\
\hline
\end{tabular}

Source: Based on UNCTAD, 2017, p. 174.

What do have all these trends have in common? First, trade in services, knowledge and digital products is highly skewed. Secondly, they strongly demonstrate the need to create or maintain a fair and level playing field for trade in services, know-how, and data. Catching-up, build-up and digital strategies are therefore part and parcel of new industrial policies. The crucial question is how to reconcile these policies with the fair- and level-playingfield argument? And thirdly, they point to the need to address tax avoidance

3 UNCTAD cautions that these results are strictly linked to the US tax system and may change with the intended changes of that system. 
strategies. A recent study by Tørsløv, Wier and Zucman (2018) has estimated that almost $40 \%$ of multinational profits are shifted to low-tax countries each year. Profit shifting is largely taking place via transfer pricing and is highest amongst U.S. multinationals. However, the tax revenue losses are estimated to be largest for the EU and developing countries.

\subsection{Rising Countries and the Great Convergence}

Participation in GVCs has brought a couple of emerging economies a dramatic rise in the standard of living, and an equally dramatic reduction in poverty. Moreover, the rise of these countries is changing the global balance of economic power, thus leading to a multi- or at least three-polar world (see Figure 3). While in terms of current US-\$, the EU and USA are still ahead of China, however, in terms of purchasing power, a truly three-polar world has already emerged.

Figure 3. Share of World GDP: EU, USA and China, 1990-2016
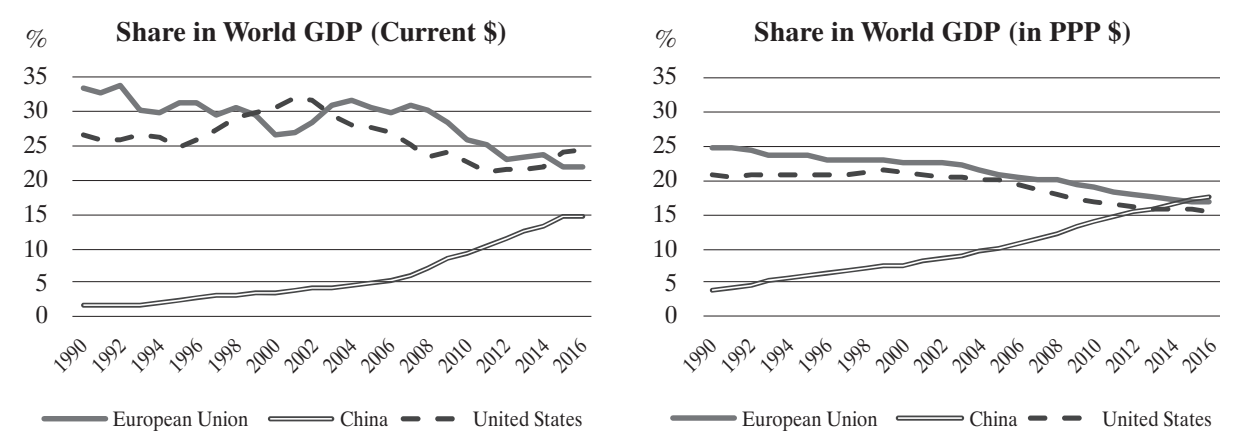

Source: Own calculations based on World Bank, World Development Indicators.

Will the "great convergence" continue, and what are the implications for the global economic geography? Three considerations are important here: First, will other countries be able to follow the model of China; second, do new technologies hold new opportunities for convergence in store for latecomer countries; third, will China continue to catch-up?

Ad (1): Can other countries, India comes to mind easily, be the next disruptors after China? To start with, most likely countries like India will develop more gradually. China-style "behind-the-wall" industrial policies will not be as effective and available because of domestic and multilateral (WTO) policy constraints. Second, the hope for relocations of tasks from China to 
neighboring cheaper production locations may not materialize as tasks in China may be robotized rather than offshored. In a similar vein, as discussed before, robotization has the potential to substitute for offshoring and eventually even leading to reshoring. Hence, the China model may no longer be a blueprint for other latecomers. Rather, developing market size (also through regional trading agreements) may be a more promising means to gain from relocations amongst neighboring countries. For example, for Chinese companies it may be more appealing to relocate production to Africa than to neighbors because of Africa's closeness to Europe and its preferential access to the EU market.

Ad (2): New technologies, especially those that are boosted by reduced faceto-face communication costs like, tele-presence and tele-robotics as argued by Baldwin (2016). These new disruptive technologies may allow workers in emerging economies to performs service tasks, like surgery, steering robots, online consulting using VR and AR technologies, etc. Hence, remote and landlocked countries that have not benefited from inclusion in GVCs in the past 30 years, may soon discover new comparative advantage in virtual tasks. Therefore the "great convergence" may go on with disruptive changes in the service sectors of advanced economies.

Figure 4. Trade in goods and services as a share of GDP (in \%) for selected regions 1960-2016

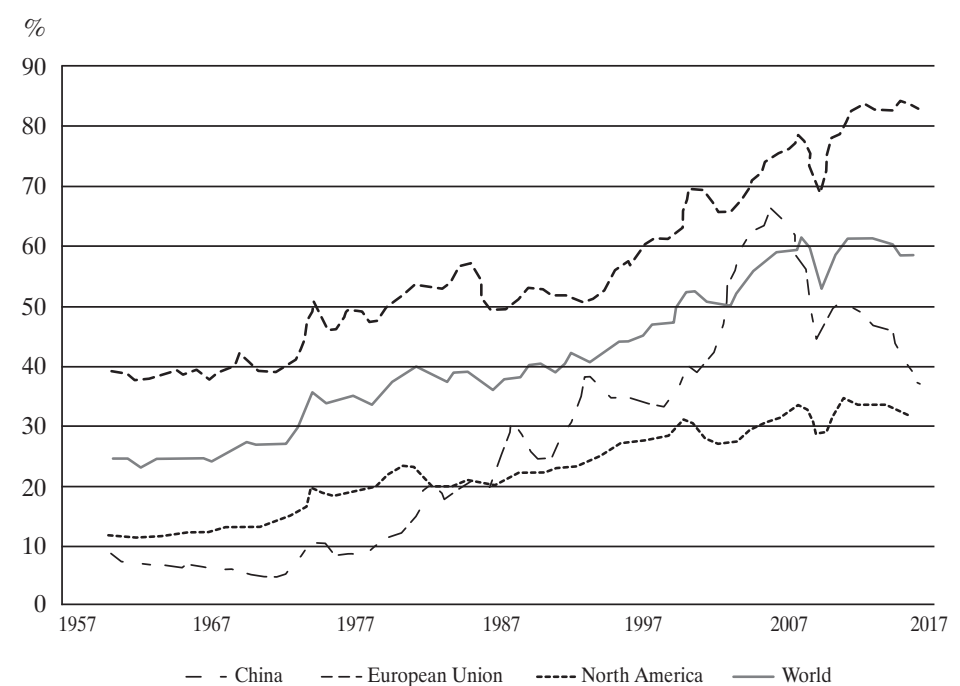

Data Source: World Bank (http://data.worldbank.org). Retrieved August 9, 2017.

Ad (3): What about China? If we look at trade integration at the regional level (Figure 4), we can observe that trade integration shows its highest 
dynamics in Asia, and here in particular in China within the first decade of the $21^{\text {st }}$ century, largely because of China's extreme participation in GVCs. As can clearly be seen, China is now disintegrating - at least relative to GDP. This has to do with three major developments: (1) the increasing importance of the Chinese domestic market, (2) a "moving-up-the-ladder" that allows to perform tasks now within China rather than relying on imported intermediate inputs and hence reshoring into China, as discussed in section 2.2, and (3) the deliberate "Made in China 2025" strategy of the Chinese government.

Moreover, China places a high emphasis on achieving technological leadership in renewable energies and other environmental-friendly technologies and products like, e.g. electric cars. And, last but not least, China state-led approach to digital technologies may give its digital industry a competitive edge, especially when it comes to AI where the sheer size of available and usable data is key to its development.

\subsection{Global Finance After the Global Financial Crisis}

At a first glance, the empirical evidence points to a global retrenchment of international finance. A closer look reveals two major changes: First, retrenchment in global banking is predominantly a European affair, and second, amongst other cross-border financial activities, FDI was the only asset category that increased relative to GDP after the GFC. However, it did so with a remarkable concentration on so-called financial centers.

To start with global banking, it must be noted that retrenchment is predominately driven by European banks. Persisting aftershock-effects of the Euro crisis, a still unhealthy banking system and a not fully fixed Eurozone architecture, especially the lack of a European deposit insurance scheme (EDIS) and limited fiscal burden sharing, has contributed to a general deleveraging of European banks, especially in global banking.

To fully understand the structural changes in global banking, it is important to distinguish two forms of banking globalization: the international business model of cross-border lending and depositing, and international model of establishing foreign affiliates by FDI (McCauley, 2011). After the GFC it was predominantly the international model that contracted, thus shifting global banking towards multinational banking. This implies that there is actually more "consolidated" exposition to foreign risks than suggested by balance-of-payments positions. ${ }^{4}$

4 The BIS reports global banking statistics on a consolidated and locational base. The consolidated statistics classify banks by nationality whereas the locational statistics classify banks by residence, similar to balance-of-payments statistics. 
Based on data from the Bank of International Settlements consolidated banking statistics (measured based on nationality of banks), McCauley et al. (2017) find that for the period 2007-2016 retrenchment was severe in the combined Euro Area plus UK and Swiss, with the notable exception of Spanish banks. US banks largely kept their international activities at the same level as before the crisis, but shifted more towards the multinational banking model and increasing the exposure slightly. McCauley et al. (2017, p. 8) therefore conclude: "Banks from the rest of the world, however, continued down the path of international financial integration ... Japanese, US, Canadian, Australian and emerging market banks expanded their foreign claims around the world, partly substituting for the retreat of European banks. In that sense, the trend towards deglobalisation is not broad-based." It should be noted that the rise of emerging economies in global banking is likely to be underestimated because many emerging economies do not report to the BIS, or have started to do that only recently, like China. However, first analyses show that emerging economy banks are rapidly integrating into global banking markets, especially Chinese banks.

Coming to cross-border direct investments, the resilience of FDI to financial crises is not entirely surprising. It is well documented that in the aftermath of a financial crisis, FDI is a much more stable source of foreign finance than bank or portfolio flows. This is not the least so because financial crises often go together with a currency crises and large devaluations increase the price competitiveness of the crisis economy. However, in a global financial crisis this narrative may not be sufficient. Lane and Milesi-Ferretti (2016) have provided an in-depth investigation of post-crisis financial integration trends and found an over-proportional role of "financial centers" in FDI, a role that increased further after the GFC. A large share of the post-crisis increase in FDI can be explained by an increase in the FDI positions of and in these jurisdictions.

Who are these "financial centers" and what kind of FDI are we talking about? Lane and Milesi-Ferretti select financial centers on the basis of their extraordinarily high ratios of external assets and liabilities to GDP, compared to the rest of the world. Next to the well-known small financial centers (such as Bermuda or the Cayman Islands), several advanced economies are also classified in this category, notably Belgium, Hong Kong, Ireland, Luxemburg, Netherlands, Singapore, Switzerland and the United Kingdom. In the aftermath of the GFC, this country group experienced a sharp contractions of cross-border banking activities, while at the same time FDI claims and liabilities increased drastically. What are the main drivers of these FDI dynamics?

To start with, the larger countries in this group are home of big multinational companies. Hence, when FDI activity increases in general, their FDI increases 
too. But this is not enough to explain both the concentration in and the huge shift of FDI towards financial centers. Lane and Milesi-Ferretti (2017, p. 14) report: "As of end-2007, residents of financial centers held some 43 percent of the world's FDI claims abroad, and FDI in financial centers accounted for around 40 percent of the global total. By end-2014, FDI claims by financial centers had risen to half of the world total, and liabilities to 44 percent." They then identify two major factors explaining the size and the recent dynamics of financial center's FDI positions.

First, the authors point to the growing importance of so-called "special purpose entities", i.e. legal entities created by parent enterprises located in other jurisdictions. The purpose of such entities is not to perform production activities. Rather, they are created to raise capital or hold assets and/or liabilities. While data on such entities are not widely available, it is documented that more than $75 \%$ of all FDI claims and liabilities in the Netherlands are related to such entities. For Luxembourg, the corresponding number even exceeds $90 \%$.

Second, the authors report an increased tendency of MNEs to move their domicile to a financial center. If only the headquarter is moved but not the production facilities, the latter will add to the FDI stocks of the financial center. Well-known tax havens like Ireland were thereby able to increase reported FDI claims by $\$ 600$ billion between 2007 and 2014, bringing FDI claims to a level that exceeds the Irish GDP by more than a factor of 5.5

In sum, post-GFC global finance is characterized by (1) the weakness of European banking, (2) a shift towards multinational banking, (3) an increasing globalization of emerging economy banks especially China, and (4) a shift of FDI towards financial centers for other reasons than production, suggesting that an "increased complexity of the corporate structure of large multinational corporations is playing an important role" (Lane and Milesi-Ferretti, 2017, 5).

\section{Globalization and the Populist Backlash}

Europe and the USA are both experiencing a wave of populism, which, especially in the case of the USA, has brought old-style protectionism back on the policy agenda, thus threatening the multilateral approaches to globalization that has ruled post-war international relationships. For our topic the core issue

5 Lane and Milesi-Ferretti (2017) remind us that in the case that the shareholders of the re-domiciled MNE remain the same, portfolio equity liabilities would increase by the same amount, thus leaving the capital account balance unchanged. 
is to what degree the rise in populism can be traced backed to economic shocks transmitted through globalization?

In a recent historical study, Eichengreen (2018) conjectures: "The history recounted here suggests that populism is activated by the combination of economic insecurity, threats to national identity, and an unresponsive political system, but that it can be quelled by economic and political reforms that address the concerns of the disaffected." He goes on defining populism as a political movement with anti-elite, authoritarian, and nativist tendencies. Hence, his definition accommodates both left-wing populism, which emphasizes the antelite element, and right-wing populism that tends to blame the "others" for their grievances.

When it comes to the recent rise of populism, two intellectual camps are swift identifying the sources: the one camp highlights the role of the economy, especially the rise of economic insecurity with globalization and especially after the GFC, the other camp argues in favor of a "cultural backlash". Eichengreen's historical account allows for a combination of both, but also emphasizes responsibility of an "unresponsive political system".

To work out the role of globalization for the rise of populism, I will first look on the distributional impact of globalization, continue then by discussing the recent (un-) responsiveness of political systems, before finally reviewing the globalization-populism nexus.

\subsection{Globalization and its Discontents}

Globalization, and especially the China shock, has both positive and negative aspects. Next to the usual gains from trade - namely lower prices for product using relatively cheaper resources from abroad - participation in GVCs can have a positive impact on labor productivity, thus increasing the international competitiveness of domestic firms. According to Constantinescu et al. (2017), a $10 \%$ increase in GVC participation increases average labor productivity by $1.7 \%$.

However, increased globalization of value chains also requires massive restructuring in advanced countries and hardship for those who lost their jobs due to the offshoring of tasks. It is now well-documented that global income distribution has changed dramatically from the 1990s onward. The evidence points to two major disruptions in distribution: first, severe redistribution effects across and within countries by income strata. Second, a pronounced fall in the share of labor income relative to the share of income going to capital. 
Redistribution effects are now famously visualized by the "Elephant Curve" (Lakner and Milavonic, 2013). The curve illustrates the growth of per-capita income by percentiles of the global income distribution from the poorest $5 \%$ on the left to the richest $1 \%$ on the right. Over the 1988-2008 period, percapita income grew on average by about $24 \%$ (or $1.1 \%$ p.a.). While the poorest $5 \%$ were clearly not fully benefitting from this growth, the middle-income strata in emerging economies did, thus lifting many people out of poverty. Inequality across countries has decreased - a process that Baldwin (2016) has called "the great convergence". For advanced countries the key concern are the developments in the upper $20 \%$ percentile: The "trunk of the elephant" shows almost stagnating per-capita incomes for the 80-90 percentile group and the underperformance of almost everyone except the upper $1 \%$. This is often read as evidence for the decline of the rich-countries' middle class while a very small elite is experiencing exorbitant income growth. Given that all this occurred at the same time when globalization rocketed, the link between the loss of well-paid (manufacturing) jobs in the rich countries due to competition from emerging economies is readily made.

However, coincidence with hyper-globalization and the rise in GVCs it not causation. As discussed before, new technologies and the emergence of digital superstar firms bear considerable responsibility for job and income losses, especially amongst less-skilled workers in advanced countries. A recent study (IMF, 2017) investigates the causes of the widespread fall of labor shares in income. It reports that in advanced countries the income share of labor has fallen by close to four percentage points between 1993-2014. About half of this fall is attributed to technological advancement, while GVC participation as well as financial integration played a much smaller role. ${ }^{6}$ The study has also decomposed the impact according to skill levels. This reveals strong redistribution effects across skill groups: high-skilled gain and low-skilled lose more than medium skilled. While these changes can only be attributed to a small amount to technology or GVC participation in the case of high and low skilled, this is not the case for medium-skilled workers. They lost a large part of their income share due to technological advances and GVC participation. However, in advanced countries, technology was an even more important factor in "hollowing-out the middle class". According to the earlier mentioned study by Acemoglu and Restrepo

6 By contrast, in emerging markets, participation in GVCs account for the lion share in the almost 6 percentage point reduction of the labor share, while technology as such played a minor role. One should, however, note that we are talking here about income shares and not absolute income. As income has been growing rapidly in several emerging countries, in particular in China, labor incomes are still rising, only not as much as capital income. 
(2018) this result can easily be reconciled with the effects of automating tasks, hence also pointing to the important role of robotization.

From this evidence one can conclude that the distribution of the gains from globalization to workers in the industrial world has become increasingly biased towards the highly skilled. Moreover, as capital shares increased, global corporation gained tremendously.

The situation has been aggravated after the GFC has pushed especially the advanced countries into a long-lasting recession in the US and in Europe. In Europe, and especially in the Eurozone, the situation has been deteriorated further by the subsequent Eurozone crisis. Whereas in a high-pressure economy the fallout of structural change can much easier be cushioned by increasing employment opportunities, the twin shocks of globalization and financial crises easily results into deep and permanent effects on income and economic security for many people.

In sum, we identified three major economic drivers of economic insecurity: GVC participation and relocation of jobs; technology and the robotization/ digitalization of jobs; and financial crises.

\subsection{The Responsiveness of Political Systems}

If history is a guidance, populism should be expected to be propelled by an "unresponsive" political system (Eichengreen, 2018) or, to put it in positive terms, populism can be contained by timely and adequate policy responses. What holds back such responses?

First, the classical argument of economists that losers from globalization can be compensated from overall gains of trade is true in principle, but unfortunately only as a theoretical option. In the practice of the past decades, global corporations were quick in using the tax-avoidance possibilities that a globalized world of investment offers, and winners of globalization successfully voted and lobbied for tax reductions rather than in favor of redistribution to bring the disfavored back into rewarding work. At the same time, the financial crisis shocks and subsequent great recession has reduces the re-employment chances of losers from globalization drastically.

Secondly, policy responses are a matter of political choice. Clearly, some cultures are less inclined to cushion structural change by social and employment policy than others. Just think of the US versus Europe, and here especially of Scandinavian countries with their generous welfare systems.

Thirdly, adequate policy responses can also be limited by available resources relative to the size of an idiosyncratic economic shock. A globalization shock 
can be so big that the means to "compensate losers" may be restricted by tax revenues, e.g. by foregone tax revenues because of tax avoidance strategies by MNEs. Alternatively, the financial crisis shocks can be so dramatic, like the GFC, that even massive policy interventions are not sufficient to avoid a deep and long-lasting recession.

Fourthly, certain institutional frameworks, such as fiscal rules limiting fiscal deficits can constitute a "policy strait jacket". This is clearly the case for the Eurozone. Within the European Monetary Union (EMU) countries can neither respond with a national monetary policy nor with a currency devaluation to an idiosyncratic shock. ${ }^{7}$ Moreover, fiscal policy in many member countries was seriously constrained by the fiscal rules of the European Stability and Growth Pact.

Finally, ideology and lack of international solidarity can also play a role. In the Eurozone, policy makers largely relied on labor market liberalization to absorb globalization and financial crisis shocks. During the Eurozone crisis, the lack of cross-border fiscal transfer mechanisms, and the unwillingness of creditor countries to accept sufficient burden-sharing across borders, has biased the bail-out packages towards a combination of austerity policy with structural reforms to induce downward wage and price adjustments. Most academic observers agree, that this policy response has seriously deepened and prolonged the crisis in many, especially southern European crisis countries.

\subsection{Globalization, Financial Crises, and the Rise of Populism}

Taking this all together, we can document increasing economic insecurity in many advanced countries, predominantly amongst the low-skilled but increasingly also threatening the middle class. However, it is difficult to single out one, or at least, the main culprit. Faced with a complex threat to their standard of living and economic security in the presence of an unresponsive policy, scapegoats are easily identified. Depending on the ideological, educational and cultural background of people, the culprits identified by right-wing populists are typically "the others" - immigration, foreign competition, etc., while left-wing populists tend to blame the "elites". Clearly, populist "political entrepreneurs" reduce the complexity of the world to offer under-complex recipes to the woes of the disenchanted.

7 As the financial crisis of 2008 was a common shock to all member countries this argument was of less relevance (though the adequacy of the monetary policy reaction of the ECB at that time is debated) than during the Euro crisis starting in 2010, which hit member asymmetrically. 
While some evidence points to the cultural hypothesis, especially when it comes to the decision left versus right populism, most recent in-depth research work identifies increased perceived and realized economic insecurity as the major source of populism. In a European-focused study, Guiso et al. (2018) investigate how the vote shares of populist parties in different European regions respond to (1) a "globalization shock" (i.e. the "China effect") and (2) to the European financial crisis of 2008-2013. Europe offers a natural experimental setting to identify the sources of populism, because the "China shock" has had a different effect on Western Europe than on Eastern Europe. In Western Europe off-shoring of tasks/jobs was frequent, whereas Eastern Europe was also a recipient of offshored tasks and jobs from Western Europe. On the other hand, the Eurozone member countries experienced a tight policy strait-jacket (dependent on the countries relative economic and fiscal position at the arrival of idiosyncratic shocks) that non-member countries did not face.

Guiso et al. (2018) use this setting to show that the globalization shock to Eastern European regions, which are most exposed to globalization, has a negative effect on populist votes, whereas in Western Europe the globalization shock has boosted votes for populist parties. This evidence suggests that winners and losers of globalization are an important factor behind populist voting. Moreover, the authors also show that in Western Europe countries, which are member of the Eurozone, the strait-jacket effect explains three quarters of the higher share of populist parties as compared to the non-Eurozone countries. In other words, the lower the discretion of countries to deal with globalization and financial crisis shocks, the higher the support for populist parties. Hence, Guiso et al. (2018, p. 4-5) argue that " The cultural backlash against globalization, traditional politics and institutions, immigration and automation cannot be an exogenous occurrence, it is driven by economic woes."

In a similar vein, in a historical study of the impact of financial crisis on voting behavior and extremist, politics covering the period 1870-2014, Funke et al. (2015) show that recessions induced by financial crises increase the vote share of far-right parties on average by $30 \%$. They were, however, unable to identify a similar effect in normal recessions or after other macroeconomic shocks. The authors therefore posit that financial crises are more likely be perceived as the result of policy failures than "normal" crises, hence traditional policy elites can easily be blamed. Moreover, they point to the fact that resolving financial crises often requires unpopular bailouts, which are seen as rewarding those responsible for the crisis in the first place. And finally, the social repercussions of financial crisis typically go deeper and are lasting longer than normal crisis. 
In sum, unaddressed societal ruptures, increased insecurity as a consequence of globalization and financial crisis shocks, instable and thus crisis-prone global, regional and financial system, while at the same time the fortunes of the top $1 \%$ and corporate tax avoidance are part and parcel of the daily news, this constitutes the soil on which populists can easily grow their authoritarian, simplistic recipes and blame scapegoats rather than addressing the real issues at stake.

\section{European Policy Options in the New Global Economy}

The implications of the new incarnation of globalization and the policy responses to it will surely shape the future of Europe. The lesson from the discussion above reveals that globalization is not sustainable in itself. Rather, without "managing" globalization and its distributional consequences, globalization tends to undermine its own foundation: the faith in open markets, societies and borders.

For Europe, open markets both within the EU as well as towards the rest of the world, are vital for its economic success model. Hence, Europe has a deep self-interest in making globalization sustainable. To contribute to it, there are many areas that require something ranging from attention to severe policy actions. The potential "to-do-list" is long and can be found on the websites of numerous initiatives, think tanks, and EU directorates. It is coalescing around the topics of digitalization, populism, inequality, competitiveness and so forth. But next to drawing up to-do-lists, the potential policy responses pose an assignment challenge: At what level should they be addressed: at the national, the European level, or at the global level? In what follows, I will first comment on the "laundry list" of the most pressing policy areas, before addressing the issue of the governance.

\subsection{Areas of Policy Responses}

In a speech at the 2017 Economic Policy Symposium of the Federal Reserve Bank of Kansas City in Jackson Hole, ECB president Mario Draghi argues: "People are concerned about whether openness is fair, whether it is safe and whether it is equitable." 
Starting with the issue of equity it is a commonplace amongst trade economist that opening up to trade creates winner and losers within a society. Since there is a strong case for net benefits from trade, economists prefer compensation of losers over protectionism. The trouble with compensation is, that more often than not it is not sufficient or even does not take place at all. Addressing the distributional consequences can be done by compensating the losers through its welfare system, by re-distribution though the national tax systems, and by re-training.

With the proliferation of GVCs, it became evident that competition is not anymore about goods between firms across countries but between individual workers on a global market place for tasks (Baldwin, 2006). The offshoring of tasks can happen at any time. "Suddenness" and "unpredictability" are the main features of fragmentated global production. Additionally, the emerging robotization of tasks, and their subsequent off- and reshoring will alter the required skills drastically towards team capabilities, digital literacy, adaptability, flexibility, and the ability to learn-to-learn. Moreover, the advent of face-to-face digital communication will increasingly make high-skilled jobs vulnerable, too.

Old-style protectionism of industries can therefore not be a successful instrument to cope with digitalization and the new globalization. Instead, focusing on education, learning to learn, and adaptability is the response of choice. The key to successful (re-) distribution policy today is not anymore to protect industries but to protect people (Baldwin, 2006). Moreover, because digitalization and globalization has contributed to reduce the share of global income going to labor, and thus to increased inequality within many countries, addressing inequality beyond protection of losers of globalization has become a pressing political issue, too.

However, as the above discussion has revealed, the impact of globalization on equity is often indistinguishable from the impact of technology: it does not make a difference whether your job will be taken over by a robot or by workers abroad. In both cases this involves job and temporary or even permanent income losses. What separates trade from other structural changes is the issue of fairness. Rodrik (2017) has argued that redistribution policies alone are not satisfactory to deal with the challenges of globalization: "That brings us to a different social and political objection to trade - that trade violates norms embodied in our institutional arrangements. The suggestion here is that trade may undercut the social bargains struck within a nation and embedded in its laws and regulations. ...Trade is not merely a market relationship, but an intervention into domestic institutions and an instrument 
for reconfiguring them to the detriment of certain groups." As a consequence, Rodrik finds it justified to respond to "social dumping", for example when foreign competitors undercut wages by means of abusing workers' rights (political wage suppression, forced labor, etc.) in a similar way as nations respond to general "price dumping". His idea is basically to protect the national social compacts via national anti-dumping policies rather than by a multilateral response.

In contrast, Mario Draghi (2017) has argued in favor of a multinational approach to address fairness (and safety) issues: “...multilateral cooperation, leading to regulatory convergence, is a precondition for addressing the underlying causes of these concerns. To demonstrate this, let me draw on our experience of managing openness within the European Union. As regards fairness, the point is obvious: regulatory convergence provides the strongest assurance that the playing field is level right across the European market. This is why, as borders have opened within Europe, common supranational powers of legislation and enforcement have strengthened in parallel. Similarly, what has permitted the Single Market to survive various financial and consumer protection crises is its ability to restore safety by adapting market-wide regulation and enforcement."

However, European regulatory convergence is not only an attractive instrument to create a fair and level European playing field. Witness the recent experience with the European "General Data Protection Regulation (GDPR). The Economist (22nd September 2018, p. 13) argues that "the principles of the GDPR are now being used as a benchmark for good data practice in markets well beyond Europe". With its huge single market, the EU can use its regulatory competence to not only make Europeanization but also globalization fairer in the eyes of their citizen. Given the new realities of the global economy, the key areas for effectively influencing or at least contributing to global regulatory best-practices are clearly in the areas of tax avoidance, race-to-the-bottom tax competition, labor rights, financial stability, and other multilateral initiatives towards regulating global finance, trade, investment, know-how, and data exchange. A Europe that firmly addresses these issues within the EU and beyond, thus setting a global agenda on addressing fairness in a multilateral setting, can contribute significantly to make globalization not only fair, safe and equitable, but also sustainable.

A Europe that puts people first with respect to equity and addresses the fairness issue seriously within Europe and at the multilateral level by highlighting the core issues that concern people, will produce visible results that will surely appreciated by European electorates. 


\subsection{European Governance}

\subsubsection{The European Policy Trilemma}

At what level should decisions be made? What should remain at the level of the nation state and what should be delegated to a supranational level, be it to the European Union, or to a global, multilateral institution like the WTO? Rodrik (2011) has argued that there is a "globalization trilemma" that forces policy makers to make choices between hyper-globalization, national decisionmaking and democratic politics (see Figure 5).

Figure 5. Rodrik's Globalization Trilemma: Pick 2, only 2

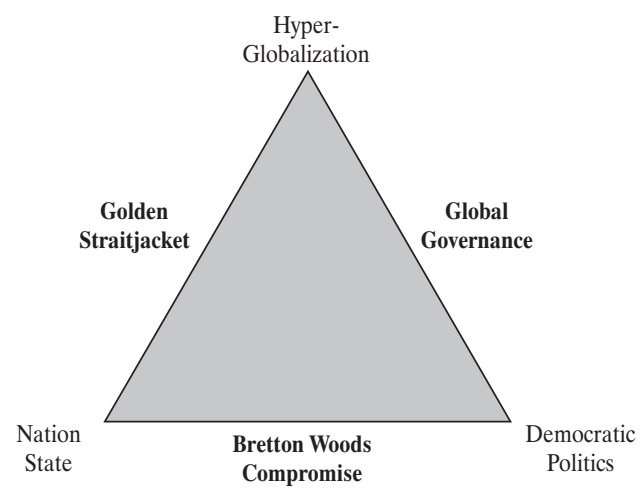

Source: Graph based on Rodrik 2011: 201.

The basic argument is that excessive globalization needs democratically legitimized global governance. Alternatively, if countries are not willing to share sovereignty with supranational institutions, they will lose democratic control in the presence of hyper-globalization. In practice they are then at the mercy of market "mechanisms". For example, the gold standard enforced automatic adjustments, if needed. The experience in the early 20th century with automatic (deflationary) adjustments was disastrous as the then young democracies and an increasingly powerful labor movement were unwilling to accept exorbitant unemployment levels as a devise to induce wage deflation. Likewise, the reliance of wage and price deflation to restore competitiveness in several countries during the Eurozone crisis has created mass employment and severely threatened the social fabric in the affected countries. Alternatively, the trilemma suggests that democratic decision-making at the level of the nation state requires to restrict hyper-globalization. 
But is the European Union, which explicitly deals with harmonizing standards across the EU, not better equipped to deal with these issues with respect to European economic integration? Benoit Cœuré (2017), Member of the Executive Board of the European Central Bank (ECB), relating to Rodrik's trilemma, argues: “... the European experience shows that these trade-offs are manageable. A variant of globalisation could be based on a parsimonious framework of international rules which leaves room for manoeuvre for national governments. In fact, the principle of subsidiarity which is firmly anchored in the Treaty on European Union can be interpreted as a regional attempt to solve Rodrik's 'political trilemma'. It aims to ensure that decisions are taken as closely as possible to the citizen and that action at European level is only taken if the objectives cannot be properly achieved at national, regional or local level".

What follows from this discussion, is that two major issues need to be addressed: First, Rodrik's trilemma might be present in some, but not all aspects of "globalization" alike. Hence, it is important to identify, which decisions are best taken at what level, depending on the issues at stake. Second, all decisions delegated to a supranational level requires some form of democratic legitimization.

\subsubsection{Rebalancing Policy Areas in Europe}

The optimal allocation of policy areas is nothing new, and a theoretical foundation can be found in standard textbooks on European integration, such as Baldwin and Wyplosz (2012) under the heading of "theory of fiscal federalism". According to that theory one should allocate decisions to the supranational level only when the benefits of doing so exceed the cost of giving-up sovereignty. Otherwise decisions are best taken at the national or even local level. In fact, allocating decision-making to the lowest level possible without giving-up net benefits is the core of the principal of subsidiarity. The major benefits of supranational regulation are rooted in scale economies and spillovers, but they have to be balanced with national preferences, which constitute the "costs". Yet, the devil is in the detail.

Starting with the issue of equity it is clear that it is predominantly the task of nation states to address distributional issues to stabilize the social fabric of a country. The national preferences regarding redistribution and the institutions of national social systems still differ widely within the EU, and it is unlikely that both will converge soon sufficiently enough to make a European approach superior. However, allocating redistribution to the nation states comes with 
three major caveats. First, structural change causes much less distress in an employment-friendly macro-economic environment, which is often beyond the full control of national government. Especially in the Eurozone, the almost (non-)existence of fiscal transfer mechanism and the coordination of macro and macro-prudential policies are important issues that need to be addressed. Secondly, trade agreements are negotiated at the EU level, but have often differential impacts on the various member countries, which calls for some kind of a transfer mechanism. ${ }^{8}$ And third, tax-avoidance strategies both within Europe and globally, which limit the resources available for redistribution, can effectively only be addressed at a supranational level.

A clear case for the superiority of European governance is the European single market, which exhibits strong scale economies. Of course, national preferences militate at times against EU product norms etc., but by-and-large the benefits grossly outweigh the costs of giving-up sovereignty. However, the cost-benefit balance is not carved in stone. For example, especially in the times of economic stress after the GFC, the "free movement of people" principle of the single market has caused disruptions and is viewed as at least partly having influenced the British Brexit vote. Hence, the EU-UK Brexit negotiations are gyrating around the (im-)possibility of getting single market access minus the "free movement of people" part, something that the EU commission strongly opposes at the time of writing.

By contrast, joint foreign policy, defense policy, migration policy and external border control, have tremendous benefits, but national preference have diverged so dramatically in the past that these areas have largely remained under national control. However, the rapidly changing geo-strategic situation is increasingly tipping the balance towards European governance in some if not all of these areas.

There are, however, key areas in which a rebalancing of governance is necessary. Most importantly, this is true with respect to the European Monetary Union (EMU). It is now broadly acknowledged that EMU as designed by the Maastricht Treaty of 1992 is a seriously flawed currency union. Basically, it created a monetary union without a banking union and without any fiscal transfer mechanisms. However, to cope with asymmetric shocks within a monetary union, it is required to have sufficient risk sharing mechanisms. In terms of Rodrik's

8 The EU has established the European Globalization Adjustment Fund (EGF) in 2007 to co-finance the reintegration of workers negatively affected by globalization. The EGF is, however, capped to a meagre amount of approximately $0.1 \%$ of the EU budget. Moreover, more than $50 \%$ of the funding has been used for dealing with the macroeconomic fallout of the financial crisis. For a detailed analysis see Claeys and Sapir (2018). 
trilemma this means that giving-up sovereignty in some policy areas is necessary to make the EMU sustainable (Sander, 2011). What is ultimately needed is subject to controversy, but there is an increasing consensus that next to some kind of fiscal risk sharing (e.g. via the European Stability Mechanism - ESM), completing the European banking union by introducing a European deposit insurance system (EDIS) is key (see e.g. Bénassy-Quéré et al., 2018). ${ }^{9}$ In other areas, especially with respect to the "fiscal strait-jacket" of the European Stability and Growth Pact, it has been argued that it may be advisable to "renationalize" fiscal policy to "give back control" (and - one must add -responsibility) to national governments over the use of their tax income (Eichengreen and Wyplosz, 2016). ${ }^{10}$ In fact, this is what they have been elected for and for what they are accountable to their voters. In other words, the governance of the Eurozone needs rebalancing, not only to make EMU sustainable, but also to cope with the rising anti-European populism (Sander, 2016).

Finally, a new and emerging major task at the European level and beyond is the dealing with global digitalization and superstar firms. There are two major areas of joint action.

First, a joint European industrial policy strategy is fundamental. UNCTAD (2018, p. 128) reports: "In the decade since the global financial crisis, the number of countries adopting national industrial development strategies has increased dramatically. ... Countries at all levels of development are using targeted industrial policies, not only for economic development purposes, but also to respond to myriad contemporary challenges, such as creating jobs and reducing poverty, participating in the technological revolution and in global value chains (GVCs), promoting efficient and clean energy and greening the economy." While those policies are often devised at the national level, at least two arguments speak for the superiority of a bold European strategy: On the one hand, globalization and digitalization have shown uneven effects within the European single market, especially to the detriment of several southern European countries that should therefore be addressed by joint initiatives. On the other hand, superstar firms are global in reach but deeply rooted in their home country, suggesting that national conditions in terms of market size, supporting industries and resources, as well as policy incentives are important to nurture such industries. The European single market is therefore key, but also

9 However, national sentiments occasionally militate against regulations that deliver net benefits, as the current debate over the EDIS reveals. Especially German preferences against the perceived risks of debt "mutualization" are currently seriously impeding the project.

10 Eichengreen and Wyplosz (2016) argue that renationalization of fiscal policy requires to address the problem of debt overhangs as well as establishing credible no-bailout rules. 
need to be complemented by a digital single market and activities in the area of knowledge and expertise, like e.g. the European Universities Initiative. While these initiatives already exist, the key is their sheer size and the willingness to transfer resources across borders to make such efforts effective.

Second, and as argued before, European regulation can be used to set or at least influence global standards in the currently highly unregulated digital markets, which ultimately can help Europe to establish and/or foster competitive advantages in digital industries.

\subsubsection{Towards a Better Democratic Legitimization of European Governance}

This brings us to the problem of democratic legitimization of decisionmaking at the supranational level. Here, the most serious problem is that most decisions are taken at an inter-governmental level, typically based on proposals prepared by the European Commission. The European parliament has some, but limited say depending on the issue. Thus, democratic legitimization comes predominantly indirectly from national elections. For national voters it is therefore often difficult to trace the decisions taken back to their voting casted at the national ballots. Does Europe therefore need a major reform of its structure and decision-making rules in the face of the new global economy?

Especially the rise in anti-European sentiments and populism within the EU makes a "business-as-usual" strategy with only some gradual adjustment a dangerous strategy. Obviously, this is seen by the EU commission too. In a White Paper on the Future of Europe (European Commission, 2017), the commission contrasts five scenarios: (1) "carrying on", meaning incremental progress towards "an ever closer union"; (2) a "focus on the single market", thus reacting passively to the differences in preferences; (3) "those who want to do more", i.e. allow for a multi-speed Europe towards the destiny of an ever-closer union; (4) focusing on selected policy areas and "doing things more efficiently", i.e. a new prioritizing, eventually after a detailed reconsideration of cost and benefits; (5) "doing more together", i.e. moving faster to a closer union. It is beyond the scope of this paper to contribute to an analysis of a rebalanced Europe in the light of these five scenarios. Nevertheless, three points will be made in the light of the discussed dual challenges of globalization and digitalization.

First, there are numerous obvious areas where benefits are overwhelming from a purely economic point of view: the single market, including open internal borders to allow European value chains to stay competitive; ${ }^{11}$ a European digital

11 I have not listed issues like migration, security and foreign policy here because they are beyond the scope of the paper. However, to allow a borderless Schengen area to function 
strategy, using the leverage of the single market to reach out with regulation beyond Europe; addressing tax avoidance; promoting rules to ensure financial stability; creating a European knowledge space; joint infrastructure investment in transport and communication, and so forth.

Second, the advantages of cooperation are less obvious in other areas, particularly with respect EMU and it is indeed questionable whether the "finalité" of the Maastricht treaty in this respect is still justified. This brings us to the issue of an ever-close-union versus a two or multi-speed Europe or a multitrack Europe. In the first case all countries are obliged head towards more integration in all areas (finalité). De facto, however, this is an illusion as some but not all member countries have (yet) joined EMU or the Schengen area. One might view Europe therefore as a two-speed union in which the EMU countries constitute the fast-integrating core, while the rest follows behind. This again, however, masks that not all EMU countries are ready or willing for fast track. Hence, in reality the EU is already at best a multi-speed Europe. Moreover, several countries simply do not share the finalité vision, i.e. prefer staying out EMU or Schengen. In this respect, it would be better to speak of a multitrack Europe. The problem with multi-track is the danger of raisin picking. But this danger has to be weighed against increasing sentiments against a too intrusive Europe governance, especially in the new member states. However, the attractiveness of participation in more or all fields of European integration under a multi-track regime crucially depends on the "output legitimacy". As shown above, there are many areas in which joint European policy actions allow to deal much better with globalization than relying on purely national policies in a world of superstar firms and rising new superpowers like China. If Europe "delivers", multi-track must not be a threat to European integration but could instead promote integration wherever constructive and advantageous.

Third, and finally, "input legitimacy" is crucial. The debate about a democratic legitimation of European decision-making is complex and revolves around strengthening the European parliament. There are many proposals out and it is beyond the scope of this paper to do full justice to all of them. But it should be noted that the reform proposals depend crucially on taking a stance regarding single versus multi-speed versus multi-track. For example, a team around the French economist Thomas Piketty, a pro-European, recommends to strengthen the powers of the European parliament as well as creating a "Eurozone Assembly" (Hennette et al., 2017). Eichengreen (2018) has criticized this approach as at best a partial solution, as it relies - in his view

smoothly, this may require more joint external border control. This argument is therefore here based on purely economic grounds. 
- on an antiquated vision of a two-tier Europe with the Eurozone at the core. He goes on suggesting to empower the existing European parliament along the lines member states participate in the various areas of European institutions and policies in a multi-track Europe. For example, members of parliament from Euro area countries vote on Euro affairs, representative from Schengen countries on Schengen-related matters and so on. This way, Eichengreen (2018) hopes that "[T]he Parliament would channel the voice of the people, rendering the technocrats of the Commission, the ECB, and other EU institutions democratically accountable, but only the voice of the relevant people-citizens of those countries that agreed to cede national prerogatives on the issue in question." And, as he adds at the end of his book, this could eventually even help containing the rise of anti-European populism on the continent.

\section{Conclusions}

Europe is facing a triple challenge from globalization, digitalization, and rising anti-European sentiments within the union and increasing populism elsewhere. What makes these challenges so difficult to deal with is that they are deeply intertwined. New technologies have been driving globalization in the past and will continue to do so, though with a changing character. Their associated and politically not sufficiently addressed socio-economic consequences have increased economic insecurity in many countries of Europe and made deep inroads into the middle-class.

However, in many cases a united Europe is better equipped to deal with globalization and global superstar firms than small nation states. Most of all, it can use its huge single market to contribute to the setting of a global agenda that puts people first in global economic affairs by promoting better global rules for digital business, labor rights, financial stability, cross-border investments and knowledge flows, and so forth.

This, however, requires a strong, functional, and better democratically legitimized European Union. The Jean Monnet dictum ' $L$ 'Europe se fera dans les crises et elle sera la somme des solutions apportées à ces crises" [Europe will be forged in crises, and will be the sum of the solutions adopted for those crises] may have worked in the past. In a globalized and digital world without a benign hegemon and guarantor of a rules-based world economy, Europe has to take up its new role as one of three superpowers. Only if Europe will go for 
a big push forward, it will be able to contribute effectively to the future of the global economy.

Europe needs to wake up and become pro-active in three aspects: increasing the legitimization of its policies by democratization, deliver in terms of wealth, prosperity and stability, and take-up global responsibility for a world economy to make the new global economy a better place to work and live in.

\section{References}

Acemoglu, D. and Restrepo, P. (2018). Modeling automation. American Economic Review Papers and Proceedings, 108, 48-53.

Autor, D., Dorn, D., Katz, L.F., Patterson, C. and Van Reenen, J. (2018). The fall of the labor share and the rise of superstar firms. MIT mimeo updated from NBER Working Paper.

Baldwin, R. (2006). Globalization: The great unbundling(s). Prime Minister's Office: Economic Council of Finland. Eu2006.fi.

Baldwin, R. (2016). The great convergence: Information technology and the new globalization. Cambridge, MA.: Harvard University Press.

Baldwin, R. and Wyplosz, C. (2012). The economics of European integration. $4^{\text {th }}$ edition. Maidenhead: McGraw-Hill.

Bénassy-Quéré, A., et al. (2018). Reconciling risk sharing with market discipline: A constructive approach to euro area reform. CEPR Policy Insight 91, January. London: CEPR.

Claeys, G. and Sapir, A. (2018). The European globalisation adjustment fund: Easing the pain from trade? Bruegel Policy Contribution 5. Brussels: Bruegel.

Coeuré, B. (2017). Sustainable globalization: Lessons from Europe. Speech at the Workshop "Financial globalization and its spillovers - monetary and exchange rate policy in times of crises". Special public event "25 years after Maastricht: The future of money and finance in Europe”, February 16. Maastricht. Acquired from: https://www.ecb.europa. eu/press/key/date/2017/html/sp170216.en.html.

Constantinescu, C., A. Mattoo and Ruta, M. (2017). Trade developments in 2016: Policy uncertainty weighs on world trade. February 21. Washington DC: World Bank Group.

Draghi, M. (2017). Sustaining openness in a dynamic global economy. Speech at the Economic Policy Symposium of the Federal Reserve Bank of Kansas City, Jackson Hole, 25 August. Acquired from: https://www.ecb.europa.eu/press/key/date/2017/html/ecb.sp170825.en.htm.

Eichengreen, B. (2018). The populist temptation: Economic grievance and political reaction in the modern era. Oxford: Oxford University Press.

Eichengreen, B. and Wyplosz, C. (2016). Minimal conditions for the survival of the Euro. In: Baldwin, R. and F. Giavazzi (eds.). How to fix Europe's monetary unions: Views from leading economists. London: A VoxEU.org eBook. CEPR.

European Commission. (2017). White paper and the future of Europe: Reflections and scenarios for the EU27 by 2015. Brussels: European Commission.

Funke, M., Schularick, M. and Trebesch, C. (2015). Going to extremes: Politics after financial crises, 1870-2014. CESifo Working Paper No. 5553. October. 
Guiso, L., H. Herrera, M. Morelli, M. and Sonno, T. (2018). Global crises and populism: The Role of Eurozone institutions". EIEF Working Papers Series 1806. Rome: Einaudi Institute for Economics and Finance.

Hennette, S., Piketty, T., Sacriste, G. and Vauchez, A. (2017). Pour un traité de démocratisation de l'Europe. Paris: Editions du Seuil.

IMF. (2017). World Economic Outlook April 2017. Washington DC: International Monetary Fund.

IMF. (2018). World Economic Outlook April 2018, Chapter 4. Washington DC: International Monetary Fund.

Lakner, C. and Milavonic, B. (2013). Global income distribution: from the fall of the Berlin Wall to the great recession. The World Bank. Policy Research Working Paper 6719, December. Washington DC: World Bank.

Lane, P.R. and Milesi-Ferretti, G.M. (2017). International Financial Integration in the Aftermath of the Global Financial Crisis. IMF Working Paper WP/17/115. Washington DC: International Monetary Fund.

Marin, D., Veugelers, R. and Felia, J. (2017). A revival of manufacturing in Europe. Recent evidence about reshoring. In: Veugelers, R. (ed.), Remaking Europe: The new manufacturing as an engine of growth (p. 102-125). Bruegel Blueprint Series 26. Brussels: Bruegel.

McCauley, R. (2011). De-internationalizing global banking? Comparative Economic Studies, 56(2), June, 257-270.

McCauley, R., Bénétrix, A.S., McGuire, P.M. and von Goetz, P. (2017). Financial deglobalisation in banking? Trinity Economic Papers No. 1717, July. Dublin: Trinity College.

Nordhaus, W.D. (2015). Are we approaching an economic singularity? Information technology and the future of economic growth. Cowles Foundation Discussion Paper No. 2021. New Haven, CT: Cowles Foundation.

Rodrik, D. (2011). The globalization paradox. Democracy and the future of the world economy. New York and London: W.W. Norton \& Co.

Rodrik, D. (2017). It's time to think yourself on free trade. Foreign Policy, January 27. Acquired from: https://foreignpolicy.com/2017/01/27/its-time-to-think-for-yourself-onfree-trade/.

Sander, H. (2011). Europe must grapple with the debt crisis now. The Conversation: Global Perspectives. May 18. Acquired from: https://theconversation.com/europe-must-grapplewith-debt-crisis-now-1264.

Sander, H. (2016). Renationalising fiscal policy would help rebuild support for the EU. EUROPP Blog: European Politics and Policy. London School of Economics and Political Science. Acquired from: http://bit.ly/2bAYUYx.

Tørsløv, T., Wier, L. and Zucman, G. (2018). The missing profit of nations. NBER Working Paper 24791. Cambridge, MA: NBER.

UNCTAD. (2017). World Investment Report 2017. Geneva: United Nations Conference on Trade and Development.

UNCTAD (2018). World Investment Report 2018. Geneva: United Nations Conference on Trade and Development.

Van Reenen, J. (2018). Increasing differences between firms: Market power and the macro-economy. Economic Policy Symposium of the Federal Reserve Bank of Kansas City, Jackson Hole, 29 July. 
Williamson, J. (1990). What Washington means by policy reform. In: J. Williamson, (ed.): Latin American readjustment: How much has happened. Washington DC: Institute for International Economics. 